\title{
EFFECT OF THE CUTTING DATE ON BLOOMING AND FRUIT-BEARING OF OSTERICUM PALUSTRE BEESSER
}

\author{
Ewa Krasicka-Korczyńska \\ Department of Botany and Ecology, Faculty of Agriculture \\ University of Technology and Life Sciences in Bydgoszcz, S. Kaliskiego 7, 85-796 Bydgoszcz, Poland \\ e-mail:kra-kor@utp.edu.pl
}

Received: 22.10 .2007

\section{S u m m a r y}

In fresh moist meadows, double-cut, located in the Bydgoszcz Canal Valley, you can find Ostericum palustre, a species of priority importance, which requires protection in the form of designation of Natura 2000 sites. The aim of the present research was to define the effect of the cutting date on blooming and fruit-bearing of $O$. palustre in meadows covered by the PO1b agro-environmental programme. Phenological observations included three populations of O. palustre. The first one occurs in a traditionally used meadow, not covered by the agro-environmental programme (2) where the date of the first cut falls in mid June. The second one is located in a meadow covered by the agro-environmental programme (1) where the first cutting date is possible from July 1 , and the third population located in a natural meadow is not agriculturally used (0).

The present research showed that individuals of $O$. palustre in the traditionally used meadows (2), prior to the first cut, reach the leaf rosette phase, while individuals which occur in the meadow covered by the agro-environmental programme (1), prior to the first cut, reach the generative tiller phase. Full bloom of $O$. palustre in the traditionally used meadows occurs after July 20 , while individuals of $O$. palustre in the agro-environmental programme reach that phase only at the beginning of August. At the same time, about August 6, the first inflorescence in $70 \%$ of individuals in the agriculturally unused meadow (0) has ripe fruit, and in mid August all fruits are ripe. In mid August $70 \%$ of individuals in the meadow used for traditional cutting have ripe fruits of the first inflorescence, and right before the second cut, on August 27 , almost $90 \%$ of fruits were ripe. Most $O$. palustre individuals in the meadows covered by the agro-environmental programme do not finish blooming of the first inflorescence before mid August. By the end of August, about $60 \%$ of individuals reach the phase of young fruits. The first ripe fruits occur as late as September 12. About September 20 most fruits are ripe.

To sum up, delayed PO1b agro-environmental programme meadow cutting, after July 1 , does not facilitate the production of ripe fruit in $O$. palustre individuals.

Key words: Ostericum palustre, blooming, fruit-bearing, meadow, cutting

\section{INTRODUCTION}

$O$. palustre is a rhizome perennial (hemicryptophyte) of Apiaceae family, from $0.4 \mathrm{~m}$ to $1.4 \mathrm{~m}$ high. The inflorescence is an umbel made up of 8-30 umbellules. It blooms June through September. It reproduces generatively (R u tk ow s k i, 2004). It is a Eurasian and continental species, in Poland - reaching the western limit (M e u s e 1 et al. 1978).

In Poland it is mostly found in Małopolska, Podlasie, Mazowsze, Kujawy and Wielkopolska ( $\mathrm{Z}$ a j ą c and $\mathrm{Zając,2001;} \mathrm{Bróż} \mathrm{et} \mathrm{al.} \mathrm{2002;} \mathrm{Z} \mathrm{ałuski,}$ 2004; Stasiewska, and Z ałuski, 2004; B ró ż and P odgórska, 2006). The most northern single stands were recorded in Kaszuby (M a r k ow s k i and B u 1 iń s k i, 2004).

O. palustre occurs in the habitats of moorgrass meadows of variable moisture content, alkaline peatland and fresh extensively-used meadows. In Poland, since 2001 it has enjoyed the status of a species protected by law (Dz. U. No 168). Earlier, as an endangered species, it was listed in the Polish Red Data Book of Plants (Czarna and Z ałuski, 2002). In the Kujawy and Pomorze region, it is a species endangered with extinction (V) (R utkowski 1997). It is found on the list of species which require protection by the designation of Natura 2000 areas (Dz. U. No 94). The main threats for this species include changes in the habitat caused by drying of the areas of river valleys and a change in traditional meadow management practices.

In 2004, in Poland agro-environmental programmes were introduced to protect the biodiversity in agricultural areas (Dz. U. No 174). The programme packages for different meadow types differ mainly in cutting dates to enhance the preservation of the population of birds and meadow plant species. In the PO1b package, the first cutting can be made starting from July 1. Cutting of meadows with O. palustre can considerably affect the possibility of annual 
fruit-bearing of this species, which is important to maintain the population size. It appears that seeds of many species survive for 3-5 years, and the biggest number of seeds germinates in the first year ( $\mathrm{F} \mathrm{a} \mathrm{li} \mathrm{ń} \mathrm{s} \mathrm{k} \mathrm{a,} \mathrm{1990).} \mathrm{It} \mathrm{seems,}$ therefore, necessary to define such a meadow cutting date which would allow an annual production of generative diasporas, especially in the case of rare species (B a s k in and B a sk in, 1985a, b).

The aim of the present research was to determine the effect of the cutting date on blooming and fruitbearing of $O$. palustre in meadows covered by the $\mathrm{PO} 1 \mathrm{~b}$ agro-environmental programme.

\section{MATERIALS AND METHODS}

The research was performed in fresh moist meadows, double-cut, located at Minikowo and Białe Błota, in the microregion of the Bydgoszcz Canal Valley, which is part of the Toruńska Valley mesoregion (K o n d ra c k i, 2000).

Magnocaricion association phytocenoses dominate here and the biggest patches are made up by the Carex nigra community as well as Caricetum acutiformis, Caricetum gracilis and Caricetum distichae (K r a s i c k a-K o r c z yń s k a, 2007). O. palustre occurs almost in all the phytocenoses found, most abundantly in

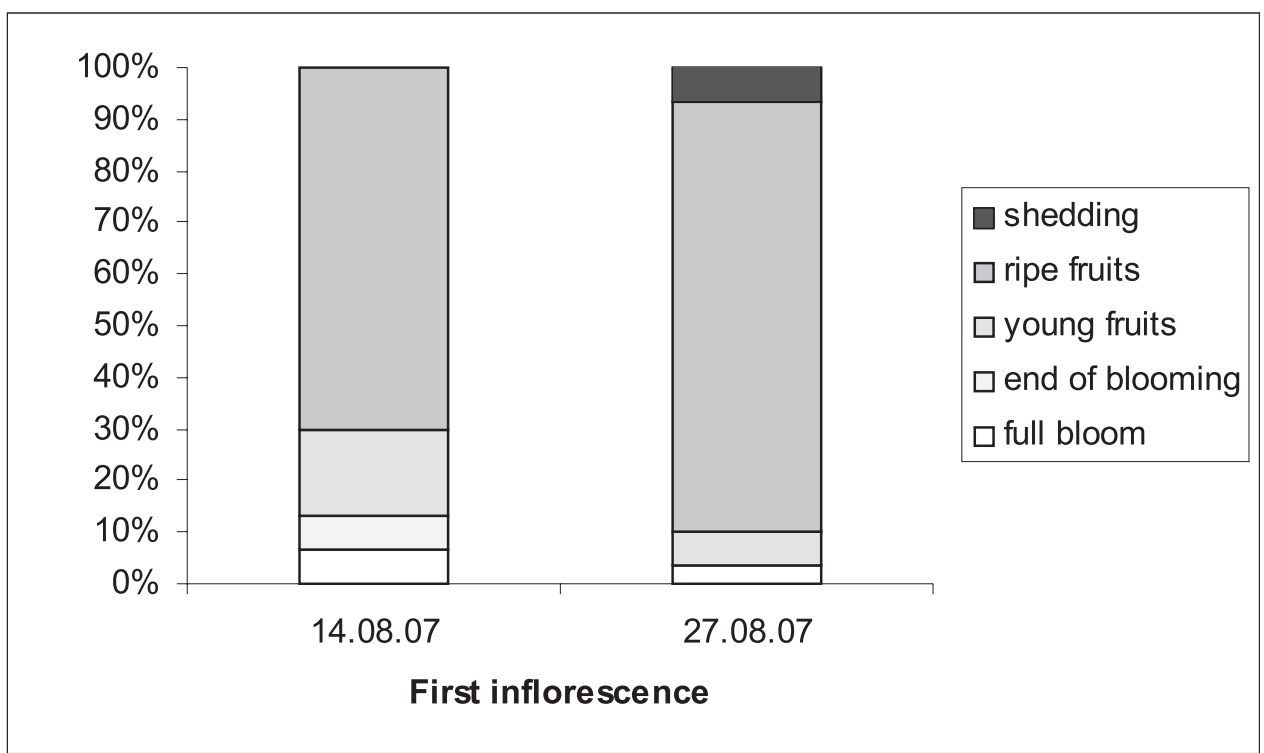

Fig. 1. Phenological spectrum of Ostericum palustre in area 2.

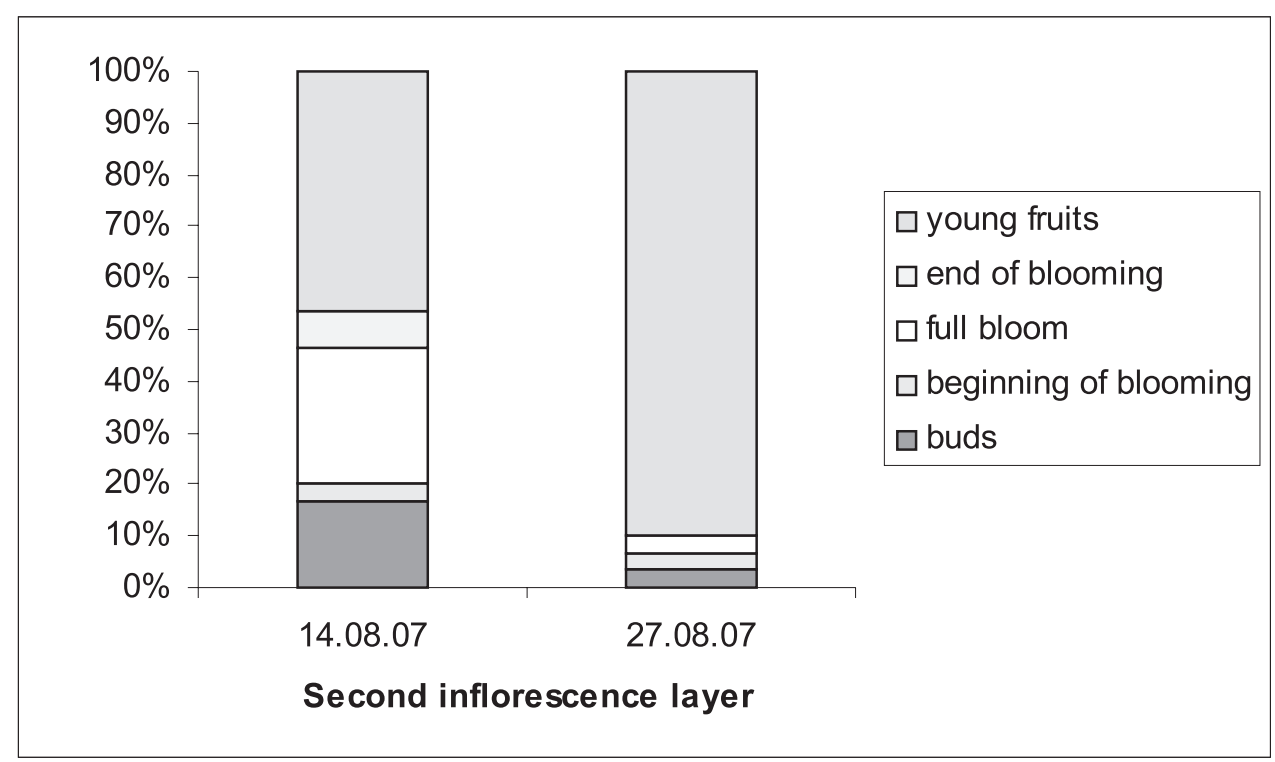

Fig. 2. Phenological spectrum of Ostericum palustre in area 2. 


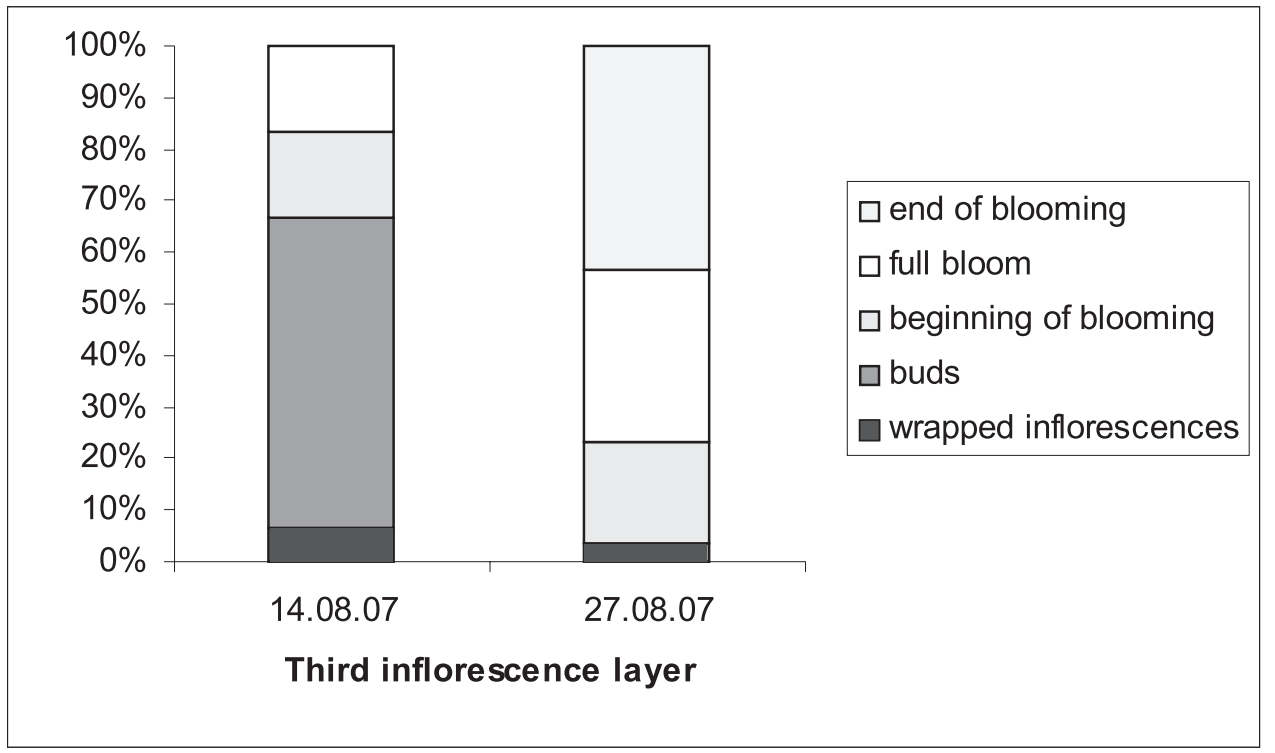

Fig. 3. Phenological spectrum of Ostericum palustre in area 2.

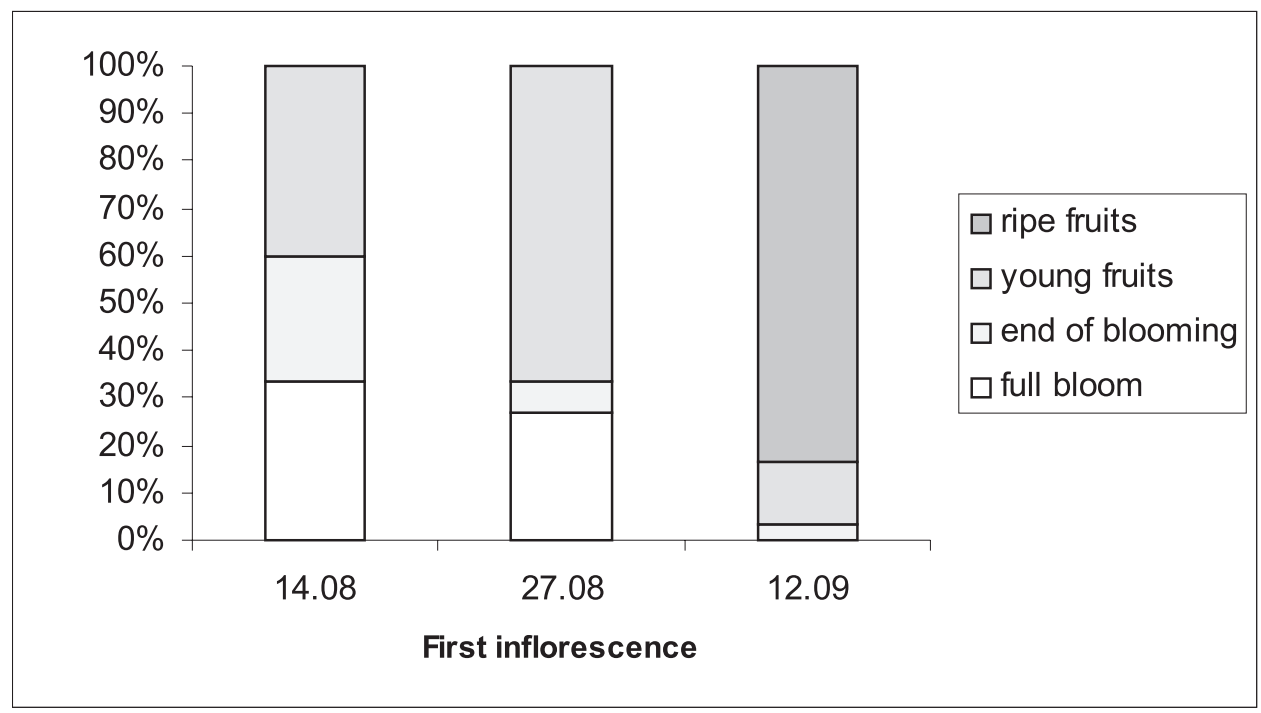

Fig. 4. Phenological spectrum of Ostericum palustre in area 1.

communities with: Carex nigra, C. gracilis, C. acutiformis and Poa pratensis-Festuca rubra. The populations of $O$. palustre covered by pheonological examinations occur in Carex nigra patches.

Observations were made in 2007, two years after the implementation of the agro-environmental programme. For the purpose of the present research, there were selected patches of three populations of Ostericum palustre located at:

1. Minikowo - meadow outside the programme (2),

2. Minikowo - meadow covered by the PO1b programme (1),

3. Białe Błota - agriculturally unused meadow (0).
The phenological observations were made for each patch using 30 randomly sampled individuals. Their beginning was defined by the date of fruit-bearing of the oldest inflorescence of the agriculturally unused meadow at Białe Błota. During the observations, the following development stages of successive umbel layers were observed: inflorescences in buds, flowers in buds, beginning of blooming ( $30 \%$ of flowers blooming), full bloom ( $75 \%$ of flowers blooming), end of blooming ( $10 \%$ of flowers blooming), young fruit, ripe fruit, shedding, shed fruit, dried inflorescence. In the respective layers of each individual, the number of umbels was recorded at the respective stages. Mean umbel numbers 


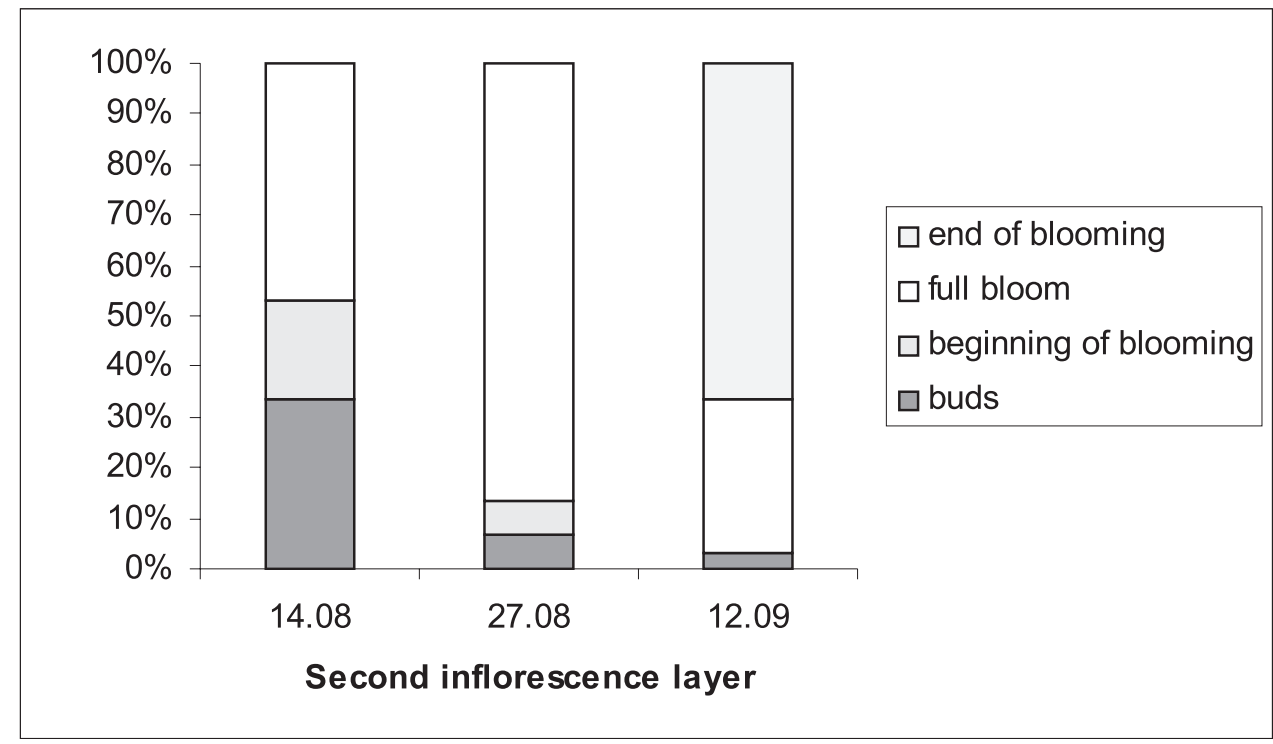

Fig. 5. Phenological spectrum of Ostericum palustre in area 1.

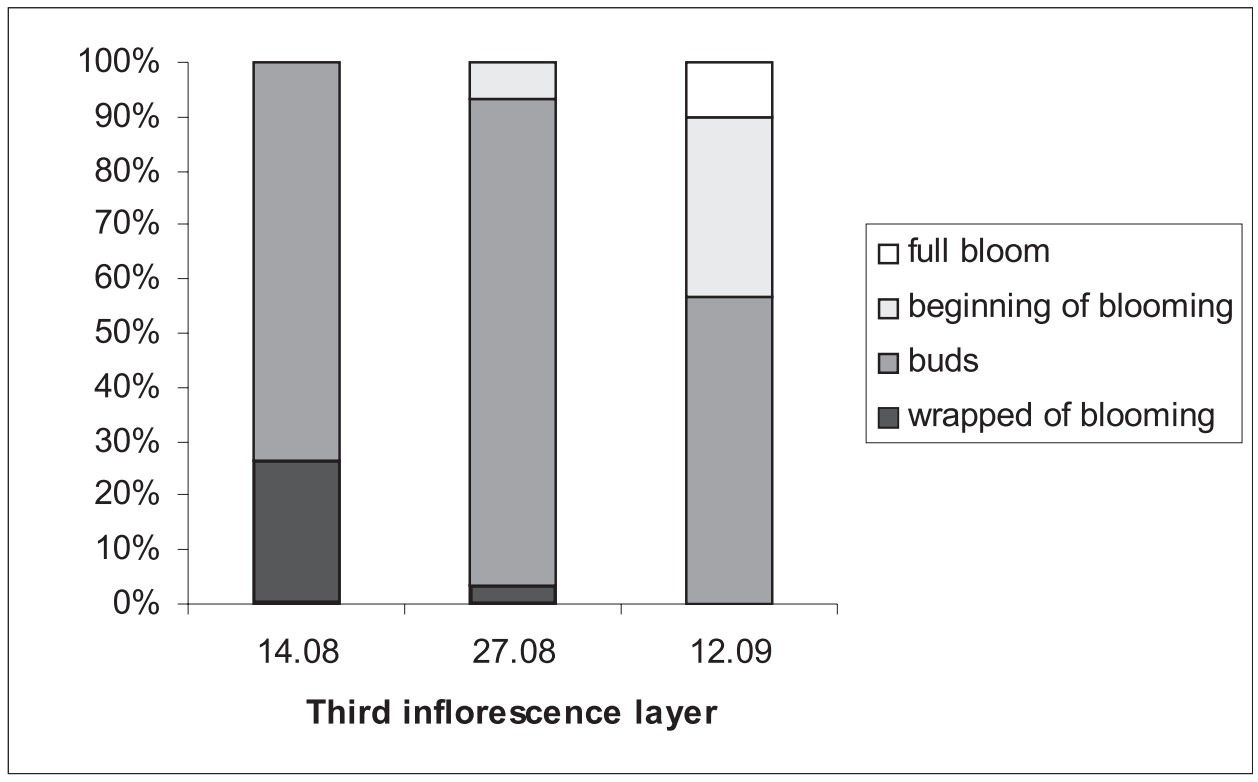

Fig. 6. Phenological spectrum of Ostericum palustre in area 1.

and standard deviations of these means were calculated. In the patches 0 and 2, four observations were made in each, and in the patch 1 three, as after the last observation the meadow was cut.

\section{RESULTS}

Individuals of $O$. palustre on the traditionally used meadows (2), prior to the first cut, reach the phase of leaf rosette most often made up of 3 fully-developed leaves which are lost by the plant with meadow sward cutting. Only after the first cut do the individuals of
O. palustre develop most often a single generative tiller. After about one month the plants bloom. Full bloom of the lowest inflorescence occurs after July 20. Three levels of inflorescences develop on the plants. The first level always produces only a single umbel, on the second one - an average of $3.88 \pm 1.24$, and on the third one - an average of $4.71 \pm 2.05$ umbels. In a few strongest individuals, the fourth inflorescence layer occurs.

The first ripe fruits occur on the lowest inflorescence about mid August and already at the end of August, right before the second cut, over $90 \%$ of fruits reach full ripeness (Fig. 1). In the second layer of umbels, 


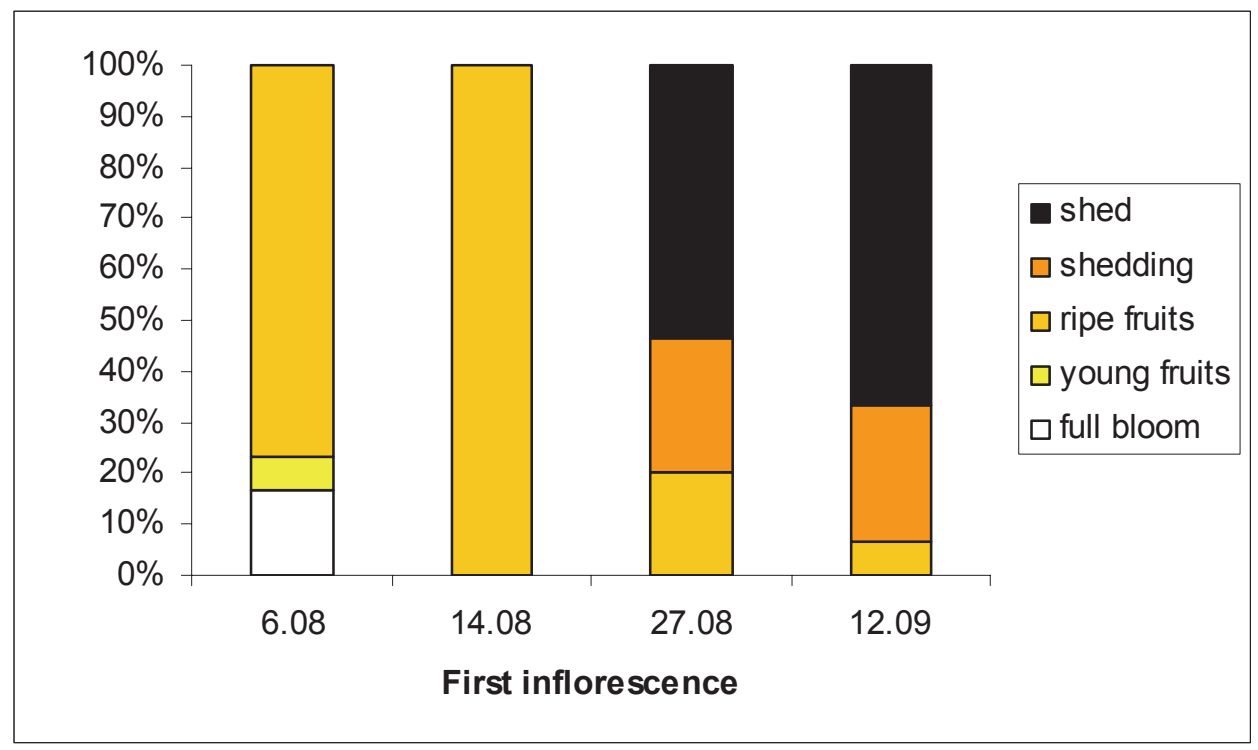

Fig. 7. Phenological spectrum of Ostericum palustre on the 0 area.

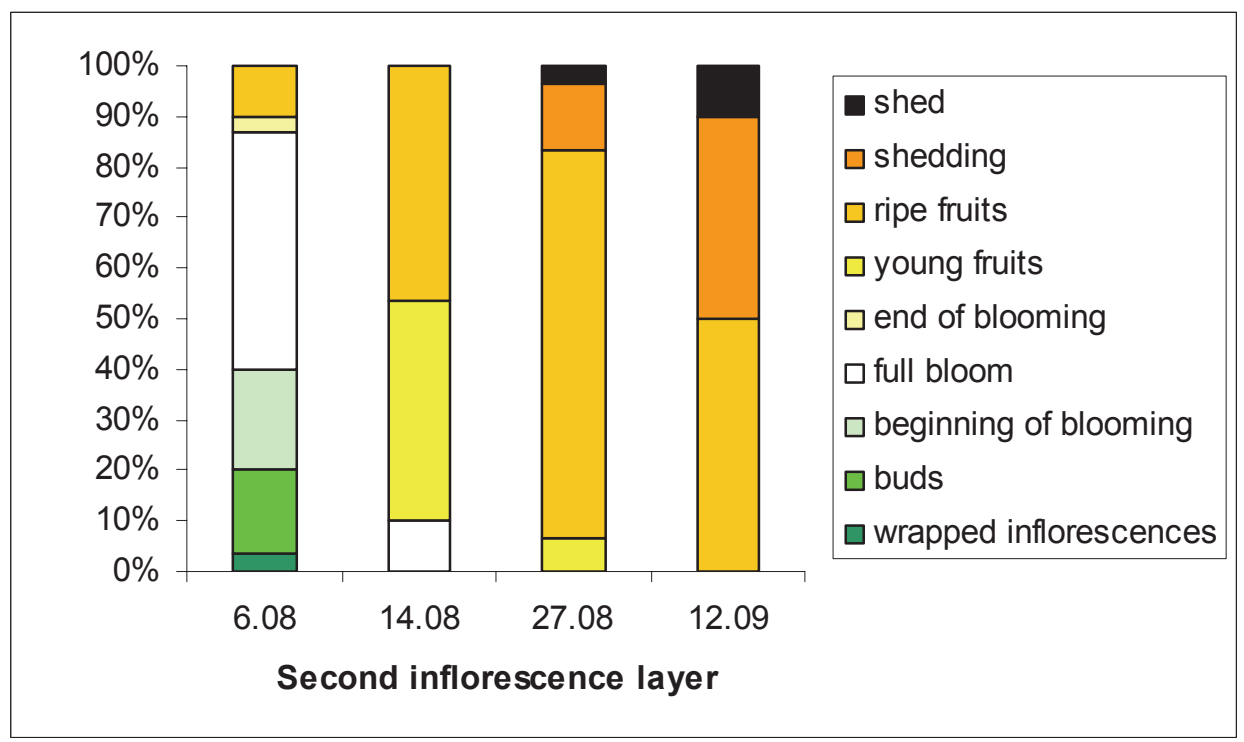

Fig. 8. Phenological spectrum of Ostericum palustre in area 0.

young fruits are found in about $50 \%$ of the individuals in mid August, while prior to the second cut - in about $90 \%$, however none of them manages to reach full ripeness before the cut (Fig. 2). On the same dates, in the third layer of umbels most flowers bloom. Prior to cutting, about $50 \%$ of flowers come out of bloom (Fig. 3 ).

In the meadows covered by the PO1b agro-agricultural programme, the first cut was made on July 10 . At that time, about $90 \%$ of the individuals of $O$. palustre developed a generative tiller. A few of them started to bloom. After cutting and another development from lateral buds of generative tillers, they reached the period of full bloom in the first week of August. By mid Sep- tember the plants also managed to develop three inflorescence layers; the first one, as usual single umbels, the second layer - an average of $4.28 \pm 1.59$ umbels, and the third one - an average of $4 \pm 2.00$. The fourth layer of umbels was not observed. In mid August in about $40 \%$ of the individuals young fruits were observed on the first inflorescence, and at the end of August - already in about $70 \%$. Fully ripe fruits on the first inflorescence were observed in about $80 \%$ of the individuals on September 12 (Fig. 4). In the second inflorescence layer, in mid August full bloom was noted. In mid September about $30 \%$ of flowers in the second umbel layer were in full bloom (Fig. 5), while in the third layer $10 \%$ of the 


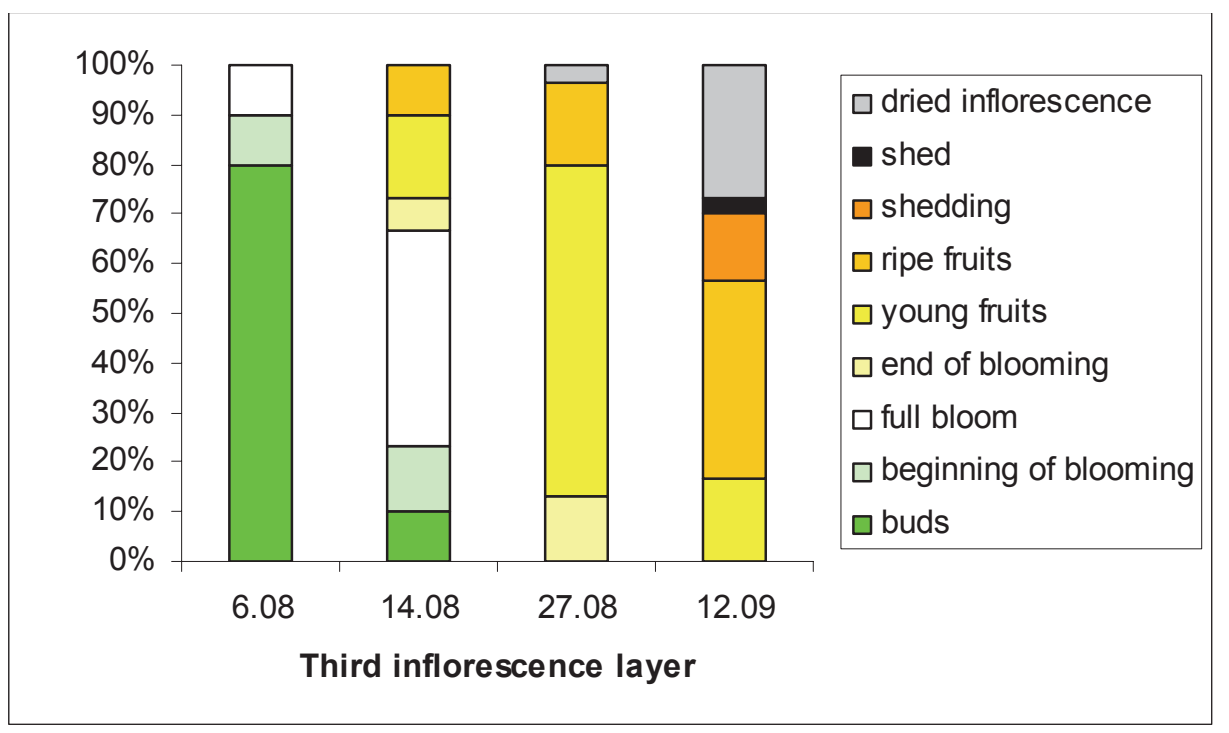

Fig. 9. Phenological spectrum of Ostericum palustre in area 0.

umbels bloomed (Fig. 6). At the same time, as a result of cold nights, flower withering was observed in the second and third umbel layers, which made fruit-setting impossible.

All the phenological stages first occurred in the meadow at Białe Błota undisturbed with agrotechnical treatments; in the first layer - a big single umbel, in the second one - an average of $7.64 \pm 1.32$ umbels, and in the third one $-18.96 \pm 6.26$, while in the fourth one $-18.10 \pm 11.03$. The fifth layer developed only in a few individuals. Ripening of the first to the last inflorescence there took 14 days. The plants produced five inflorescence layers.

Full bloom of $O$. palustre individuals occurs after July 20. On the first date of phenological observation, August 6 , in $76.6 \%$ of individuals ripe fruits were noted in the first inflorescence and already on August 27 all the fruits of these inflorescences were ripe. By mid September they shed off completely (Fig. 7). In these individuals, also all the fruits were ripe in the second inflorescence layer. Most are ripe already at the end of August, but complete shedding of inflorescences from the pedicle takes until mid September (Fig. 8). Full bloom of the third inflorescence layer occurs at the end of August. More than $50 \%$ of fruits set from these flowers ripen about mid September, but almost $30 \%$ wither as a result of cold humid nights at that time of the year (Fig. 9). For the same reasons, flowers developed in the fourth and fifth inflorescence layer did not produce ripe fruits.

\section{DISCUSSION}

For a species to survive in a given habitat, the capacity for regular production of ripe diasporas ( $\mathrm{F} \mathrm{a}$ $1 \mathrm{i}$ ń s k a, 2004) is crucial, which in turn can affect maintaining the biodiversity.
The first cut of the meadow sward, depending on the habitat and the weather pattern, occurs at the end of May. At that time most plant species are at the vegetative phase. After the cut, they reproduce the overground part and produce generative tillers, e.g. Heracleum sibiricum, Angelica sylvestris and Lythrum salicaria, which allows them to get rid of the cohort of generative diasporas. A similar reaction is recorded for $O$. palustre which, right after the first cut, produces a generative stem on which, before the second cut, fruits of the first umbel ripe. They are the only ripe fruits which guarantee the supply of diasporas to the seed bank found in these individuals.

A delayed cutting in the meadows covered by the agro-environmental programme PO1 b disturbs the plant growth at the time when most of them bloom and bear fruit. $O$. palustre individuals at the beginning of July have a fully-developed generative stem and some of them start blooming. Cutting results in a loss of almost the entire overground part, including the inflorescence. After cutting the overground part regrows from lateral buds growing from the rhizome, however it does not reach such an amount as the weight of individuals not exposed to such pressure, as reported by $\mathrm{Czar}$ $\mathrm{n} \mathrm{e} \mathrm{c} \mathrm{k} \mathrm{a} \mathrm{(1995).} \mathrm{It} \mathrm{affects} \mathrm{the} \mathrm{number} \mathrm{of} \mathrm{inflorescences}$ and flowers per inflorescence. The date of blooming and fruit-bearing is delayed almost one month. Probably also the weight of seeds produced decreases. A similar phenomenon was observed by Gę s ińs k i (1998) and S t o s i k (2006 a, b) in Plantago lanceolata and Rumex confertus.

Even though meadow habitats are grown with species which have adapted themselves to disturbances as a result of meadows being used for hay, which periodically eliminates competitors and enhances the supply of new individuals to the population, e.g. in Rumex con- 
fertus (Stos ik, 2006a), or Dactylorhiza majalis and Epipactis palustris (J u r z y k, 2007), a constant supply of new diasporas to the soil seed bank is essential. It is of special importance when meadow sward is harvested for hay-silage, which probably limits seed shedding considerably.

For the population of O. palustre in the meadows used for hay to survive in a good shape, it seems best to maintain a traditional date of the first cut. However, it is recommended to delay the harvest of the second cut of the meadow sward until the end of August to allow fruit ripening and shedding.

\section{REFERENCES}

Baskin J. M., Baskin C. C., 1985a. Life cycle ecology of annual plant species of cedar glades of Southeastern United States. [In:] The Population Structure of Vegetation. J. White (ed), dr W. Junk Publisher: 373-389.

Baskin J. M., Baskin C. C., 1985b. Seasonal changes in the germination respondent of buried witch Grass (Panicum capillare) sered. Wered. Sci. 34: 22-24.

Bróż E., Nobis M., Piwowarczyk R., 2002. Nowe stanowisko Ostericum palustre (Umbelliferae) na Przedgórzu Iłżeckim (Wyżyna Małopolska). / New stand of Ostericum palustre (Umbelliferae) on the Iłżecko Foreland (Małopolska Upland). Fragm. Flor. Geobot. Polonica, 9: 379-380.

Bróż E., Podgórska M., 2006. Starodub łąkowy Ostericum palustre Besser na Wyżynie Małopolskiej. / Ostericum palustre Besser on the Małopolska Upland, 62 (3): 3-12.

Czarna A.,Załuski T., 2002. Angelica palustris (Besler) Hoffm. Starodub łąkowy / Angelica palustris (Besler) Hoffm. [In:] R. Kaźmierczakowa, K. Zarzycki (Eds.). 2001. Polish Red Data Book of Plants. Pteridophytes and flowering plants. Polish Academy of Science, W. Szafer Institute of Botany, Institute of Nature Conservation, Cracow: 277-279.

Czarnecka B., 1995. Biology and Ecology of the Isolated Population of Senecio rivularis (Waldst. Et. Kit.) DC. and Senecio umbrosus Waldst et. Kit. Wyd. UMCS, Lublin.

Falińska K., 1990. Osobnik, populacja, fitocenoza, PWN, Warsaw.

Falińska K., 2004. Ekologia roślin. Wydawnictwo Naukowe PWN, Warsaw.

Gęsiński K., 1998. Morphological differences of the population of Plantago lanceolata L. in Kwiecko lake inundated zone. Zesz. Nauk. Akad. Tech. - Rol. Bydg. 190, Roln. 36: 21-28.

Jurzyk S., 2007. Relationships between management of most meadow and number of Epipactis palustris (L.) Crantz and Dactylorhiza majalis (Rchb.) P. F. Hunt \& Summerh. [In:] E. Kępczyńska, J. Kępczyński (Eds.) 2007. Botany in Poland, successes, problems, perspectives. $54^{\text {th }}$ PTB Meeting, Szczecin.

Kondracki J. 2000. Geografia regionalna Polski. Wydawnictwo Naukowe PWN, Warsaw.

Krasicka-Korczyńska E., 2007. Share of Ostericum palustre Beesser in biochores of agro-environmental programme
PO1b meadows. Botanische Jahrbücher für Systematik, Pflanzengeschichte und Pflanzengeografie (in print).

Markowski R., Buliński M., 2004. Ginące i zagrożone rośliny naczyniowe Pomorza Gdańskiego. / Vascular plants on the brink of extinction and threatened with extinction Acta Bot. Cassub. Monographiae, 1: 1-175.

Meusel H., Jäger E., Rauschert S., i in. 1978. Verlgleichende Chorologie der zentraleuropäischen Flora. Bd. II. G. Fischer Verl., Jena.

Rutkowski L., 1997. II Rośliny naczyniowe - Tracheophyta. [In:] Czerwona lista roślin i zwierząt ginących i zagrożonych w regionie Kujawsko-Pomorskim/ Part 2 Vascular plants - Tracheophyta. [In:] Red list of plants and animals on the brink of extinction and threatened with extinction in the Kujawy and Pomorze Region. Acta Univ. Nicol. Copernici. Biologia 53 supl. Nauki Mat.-Przyr. 98: 5-19.

Rutkowski L., 2004. Identification key to vascular plants of Lowland Poland. Wydawnictwo Naukowe PWN, Warsaw.

Decree of the Minister of the Environment of May 16, 2005 on the types of plant and animal habitats which require protection by the designation of Natura 2000 areas (Dz. U. No 94, item 795 of May 16, 2005).

Decree of the Minister of the Environment of July 9, 2004 on protected wild plant species (Dz. U. No 168, item 1764, of 09-07-2004, Attachment 3).

Decree of the Council of Ministers of July 20, 2004 on detailed conditions of financial assistance to support agro-environmental projects and enhancement of animal welfare covered by the rural areas development plan (Dz.U. No 174, item 1809 of July 20, 2004).

Stasiewska K., Załuski T., 2004. The occurrence of Ostericum palustre in plant communities in the area of Pałuki and northern Kujawy. [In:] Jendrzejczak E. (Eds.) Przyroda Polski w europejskim dziedzictwie dóbr natury, 53 Zjazd PTB, PTB, Bydgoszcz / Poland's nature in the European natural heritage, 53th PTB Meeting, PTB, Bydgoszcz.

Stosik T., 2006 a. Generative reproduction efficiency and the population age structure of Rumex confertus Willd. Acta Agrobot. 59 (2), p. 85-93.

Stosik T., 2006 b. Habit and biomass structure of Rumex confertus Willd. Under diverse ecological conditions. Pr. Komis. Nauk Rol. i Biol. BTN. Ser. B, 57: 1-13.

Zając A., Zając M. (Eds.). 2001. Distribution Atlas of Vascular Plants in Poland. Edited by Laboratory of Computer Chorology, Institute of Botany, Jagiellonian University and Foundation of Jagiellonian University, Cracow.

Załuski T., 2004. Ostericum palustre Besler, starodub łąkowy. [In:] Sudnik-Wójcikowska B., Werblan-Jakubiec H. (Eds.) Gatunki roślin. Poradniki ochrony siedlisk i gatunków Natura 2000 - poradnik metodyczny. Tom 9. Ministerstwo Środowiska, Ostericum palustre Besler [In:] Sudnik-Wójcikowska B., Werblan-Jakubiec H. (Eds.) Plant species.

Habitat and species protection manuals; Natura 2000 - methodological manual. Volume 9. Ministry of the Environment. 


\section{Wpływ terminu koszenia na kwitnienie i owocowanie Ostericum palustre Beesser}

\section{Streszczenie}

Na łąkach wilgotnych, turzycowych, użytkowanych dwukośnie, położonych w Dolinie Kanału Bydgoskiego wystepuje $O$. palustre, gatunek o znaczeniu priorytetowym, wymagający ochrony w formie wyznaczania obszarów Natura 2000. Zagadnienia owocowania są podstawowym warunkiem zachowania populacji tego gatunku. Celem badań było określenie wpływu terminu koszenia na kwitnienie i owocowanie $O$. palustre, na łąkach objętych programem rolnośrodowiskowym PO1b, mającym wspierać zachowanie różnorodności biologicznej. Do obserwacji fenologicznych wybrano trzy populacje. Pierwsza z nich występuje na łące użytkowanej tradycyjnie, nie objętej programem rolnośrodowiskowym (2), gdzie termin I pokosu przypada na połowę czerwca. Druga położona jest na łące objętej programem rolnośrodowiskowym (1), gdzie termin I pokosu możliwy jest od 1 lipca i trzecia populacja zlokalizowana na łące naturalnej, nie użytkowanej rolniczo (0).

W wyniku przeprowadzonych badań okazało się, że osobniki $O$. palustre na łąkach użytkowanych tradycyjnie (2), przed I pokosem osiagają fazę rozety liściowej. Tracą ją w trakcie pierwszego pokosu, po czym wydają pęd generatywny, który około 20 lipca jest w pełni kwitnienia, a w końcu sierpnia, tuż przed II pokosem, rośliny wydają dojrzałe owoce na pierwszym kwiatostanie.

Osobniki O. palustre występujące na łące objętej programem rolnośrodowiskowym (1), przed I pokosem osiaggają fazę pędu generatywnego, który tracą w czasie koszenia. Reakcją obronną gatunku jest wytworzenie 2 do 3 nowych pędów generatywnych z pączków przybyszowych kłącza. Pełnia kwitnienia na tych pędach przypada dopiero na początku sierpnia, a owoce pierwszego kwiatostanu osiagają pełną dojrzałość w połowie września, pod warunkiem, że wcześniej nie zostaną skoszone w ramach II pokosu. Na obydwu użytkowanych rolniczo łąkach nie dojrzewają owoce dalszych pięter kwiatostanów.

W tym samym czasie, około 6 sierpnia, I kwiatostan osobników występujących na łące nie użytkowanej rolniczo (0), w $70 \%$ ma dojrzałe owoce, a w połowie sierpnia dojrzewaja już wszystkie. Do końca sierpnia dojrzewają owoce drugiego poziomu kwiatostanów, a do połowy września dojrzewają owoce trzeciego poziomu kwiatostanów.

Podsumowując, opóźnione od 1 lipca koszenie łąk objętych programem rolnośrodowiskowym PO1b, nie sprzyja wydaniu dojrzałych owoców u osobników O. palustre. 